\title{
PENINGKATAN HASIL BELAJAR MATEMATIKA SISWA MELALUI MODEL PEMBELAJARAN KOOPERATIF TIPE JIGSAW PADA MATERI LINGKARAN DI KELAS VIII
}

\author{
Dwi Waryanti ${ }^{1)}$ \\ Jefferson Roosevelt Watulingas ${ }^{2)}$ \\ Azainil $^{3)}$ \\ ${ }^{1), 2), 3)}$ Program Studi Pendidikan Matematika FKIP Universitas Mulawarman \\ ${ }^{1)}$ Email: dwiwaryanti024@gmail.com
}

\begin{abstract}
ABSTRAK
Penelitian ini bertujuan untuk mengetahui peningkatan hasil belajar matematika siswa melalui model pembelajaran kooperatif tipe jigsaw pada materi lingkaran di kelas VIII. Jenis penelitian ini merupakan penelitian tindakan kelas. Subjek penelitian adalah siswa kelas VIIIB sebanyak 32 siswa dan objek penelitian adalah model pembelajaran kooperatif tipe jigsaw. Data diperoleh dari dokumentasi, yaitu nilai dasar, Lembar Kerja Peserta Didik (LKPD), kuis, tes akhir siklus, dan observasi. Penelitian ini dilakukan sebanyak tiga siklus, untuk setiap siklus dilaksanakan sebanyak tiga kali pertemuan. Dalam penelitian, peneliti bertindak sebagai pelaksana dalam pembelajaran, sedangkan guru matematika kelas VIII-B dan rekan peneliti sebagai observer. Teknik analisis data menggunakan statistik deskriptif berupa nilai rata-rata hasil belajar siswa dan persentase peningkatan hasil belajar siswa. Hasil analisis data menunjukkan terjadinya peningkatan nilai rata-rata hasil belajar siswa, peningkatan persentase ketuntasan, serta peningkatan hasil observasi terhadap aktivitas guru dan siswa pada setiap siklus. Hasil penelitian menunjukkan bahwa terdapat peningkatan hasil belajar matematika siswa melalui model pembelajaran kooperatif tipe jigsaw pada materi lingkaran di kelas VIII.
\end{abstract}

Kata kunci: Hasil Belajar, Kooperatif, Tipe Jigsaw

\begin{abstract}
This study aims to determine the increase in student mathematics learning outcomes through the jigsaw cooperative learning model on circle material in class VIII. This type of research is a classroom action research. The research subjects were 32 students of class VIII$\mathrm{B}$ and the object of the research was the jigsaw cooperative learning model. Data obtained from documentation, namely basic scores, Student Worksheets (LKPD), quizzes, final cycle tests, and observations. This research was conducted in three cycles, for each cycle there were three meetings. In research, researchers acted as implementers in learning, while mathematics teachers of class VIII-B and fellow researchers were observers. The data analysis technique used descriptive statistics in the form of the average value of student learning outcomes and the percentage of student learning outcomes improvement. The results of data analysis showed an increase in the average value of student learning outcomes, an increase in the percentage of completeness, and an increase in the results of observations on teacher and student activities in each cycle. The results showed that there was an increase in student mathematics learning outcomes through the jigsaw cooperative learning model on circle material in class VIII.
\end{abstract}

Keywords: Learning Outcomes, Cooperative Type Jigsaw 
Matematika adalah salah satu mata pelajaran wajib dari jenjang sekolah dasar sampai jenjang sekolah menengah atas. Matematika dikatakan sebagai ratu dan juga pelayan ilmu. Umumnya setiap orang di dunia menerapkan ilmu matematika pada kehidupan sehari-hari dari berbagai bidang. Namun kenyataannya siswa beranggapan bahwa matematika adalah pelajaran yang menakutkan dan sulit untuk di pahami. Hal tersebut merupakan salah satu penyebab hasil belajar matematika di SMP Negeri 1 Samarinda tergolong rendah. Fakta di lapangan menunjukkan bahwa umumnya siswa kurang memberi respons yang positif terhadap pelajaran matematika sehingga menimbulkan kesulitan dalam belajar dan berdampak pada rendahnya hasil belajar siswa. Hal ini diakibatkan oleh kurangnya perhatian siswa dalam mengikuti proses pembelajaran, kurangnya komunikasi siswa dan guru, serta kurangnya motivasi, penguasaan konsep dan juga prestasi belajar pada pelajaran matematika rendah.

Cara untuk mengelola pembelajaran agar siswa tidak berpandangan buruk tentang pelajaran matematika yaitu guru harus memiliki keterampilan untuk menarik perhatian siswa agar dapat menerima pelajaran dengan baik (A. Jihad, 2008:160161). Keterampilan guru tersebut digunakan untuk menarik minat siswa dalam belajar matematika yaitu dengan menggunakan model pembelajaran yang sesuai dengan materi yang diajarkan. Untuk mengatasi masalah tersebut maka perlu adanya suatu proses pembelajaran yang membuat siswa lebih aktif yaitu dengan memberikan model pembelajaran kooperatif. Model pembelajaran kooperatif merupakan model pembelajaran berkelompok sehingga siswa diharapkan dapat bekerja sama dengan siswa lain guna mencapai tujuan bersama. Dilihat dari permasalahan tersebut maka model pembelajaran yang cocok untuk diteliti adalah model pembelajaran kooperatif tipe jigsaw karena siswa saling memberikan kepercayaan dan kesempatan bagi siswa lain untuk berani mengemukakan pendapat, menghargai pendapat temannya, saling bekerja sama, dan juga dapat meningkatkan keaktifan siswa dalam belajar serta meningkatkan komunikasi atau interaksi antar siswa dan guru sehingga hasil belajar matematika siswa meningkat.

Salah satu dari beberapa topik dalam pembelajaran matematika di semester genap adalah lingkaran. Materi lingkaran juga banyak digunakan pada materi pelajaran lainnya. Berdasarkan latar belakang tersebut maka peneliti tertarik untuk melakukan penelitian yang berjudul "Peningkatan Hasil Belajar Matematika Siswa Melalui Model Pembelajaran Kooperatif Tipe Jigsaw pada Materi Lingkaran di Kelas VIII".

Hasil belajar menurut Purwanto (2016:46) ialah perubahan perilaku mahasiswa yang diakibatkan karena kegiatan belajar. Perubahan perilaku disebabkan karena tercapainya penguasaan atas sejumlah materi yang diberikan dalam proses belajar mengajar. Pencapaian tersebut didasarkan dari tujuan pengajaran yang telah ditetapkan. Hasil tersebut berupa perubahan aspek kognitif, afektif dan psikomotorik. Jihad (2009:15) berpendapat bahwa hasil belajar ialah perubahan perilaku siswa setelah dilakukan proses belajar mengajar yang sesuai dengan tujuan pengajaran.

Jigsaw menurut Kurniasih (2017:24-25) ialah model pembelajaran kooperatif yang 
dirancang untuk meningkatkan rasa tanggung jawab siswa terhadap pembelajarannya sendiri maupun pembelajaran orang lain. Siswa tidak hanya menerima materi yang diberikan, tetapi mereka juga harus siap memberikan dan mengajarkan materi tersebut kepada kelompoknya. Dalam model pembelajaran jigsaw keaktifan siswa sangat diperlukan, dengan dibentuknya kelompok-kelompok kecil yang beranggotakan 3-5 orang yang terdiri dari kelompok asal dan kelompok ahli.

Sintaks dari pembelajaran kooperatif tipe jigsaw menurut Kurniasih (2017:27-28) yaitu sebagai berikut.

1. Persiapan yaitu menjabarkan isi topik secara umum, memotivasi siswa dan menjelaskan tujuan pembelajaran

2. Penjelasan materi

3. Guru membagi siswa ke dalam kelompok asal dan ahli yaitu kelompok dalam pembelajaran beranggotakan 4 siswa yang heterogen

4. Guru menentukan skor awal masingmasing kelompok yaitu skor rata-rata siswa yang diambil dari kuis atau nilai tertentu yang telah ditetapkan

5. Rencana kegiatan

a. Setiap kelompok membaca dan mendiskusikan sub topik masingmasing dan menetapkan anggota ahli

b. Anggota ahli dari masing-masing kelompok asal berkumpul

c. Anggota ahli kembali ke kelompok asal untuk menjelaskan topik yang didiskusikannya

d. Siswa mengerjakan tes individual e. Pemberian penghargaan kelompok berupa skor individu dan skor kelompok

6. Melakukan evaluasi yaitu mengerjakan kuis individual yang mencakup semua topik

Penelitian Tindakan Kelas (PTK) yang peneliti gunakan ada 6 tahapan berbeda dengan PTK yang biasanya (4 tahapan) karena selama ini masih kurang pada bagian permasalahan dan analisis data.

\section{METODE PENELITIAN}

Penelitian ini adalah Penelitian Tindakan Kelas (PTK) yang terdiri dari 3 siklus dan masing-masing siklus terdiri dari 3 pertemuan. Pada pertemuan pertama dan kedua setiap siklusnya dilakukan proses pembelajaran melalui model pembelajaran kooperatif tipe jigsaw, sedangkan pada pertemuan ketiga setiap siklusnya digunakan untuk memberikan tes akhir siklus guna mengetahui peningkatan hasil belajar matematika siswa.

Ada 6 tahapan dalam penelitian tindakan kelas yang dikemukakan oleh Asmani yaitu sebagai berikut.

1. Permasalahan pada setiap siklus akan diberi pemecahan masalah dan akan diperbaiki pada siklus berikutnya

2. Perencanaan tindakan yaitu membuat soal tes kemampuan awal, skenario pembelajaran, RPP, mengelompokkan siswa, membuat LKPD, soal kuis, alat evaluasi hasil belajar, serta lembar observasi aktivitas guru dan siswa (melihat kondisi belajar mengajar di kelas saat proses pembelajaran berlangsung) 
3. Pelaksanaan tindakan yaitu melaksanakan skenario dan rencana pembelajaran

4. Observasi dilaksanakan bersamaan dengan tahap pelaksanaan

5. Analisis data berupa tes akhir siklus dan hasil pengamatan melalui lembar observasi

6. Refleksi yaitu mengkaji hasil observasi dan hasil belajar siswa untuk didiskusikan kemudian dituntaskan dengan tindakan perbaikan

Penelitian ini dilaksanakan pada tanggal 10 Februari sampai dengan 09 Maret 2020. Adapun tempatnya adalah di SMP Negeri 1 Samarinda Jalan Drs. H. Anang Hasyim Kelurahan Air Hitam Samarinda Ulu Kalimantan Timur Kode Pos 75124.

Subjek pada penelitian ini adalah siswa kelas VIII-B SMP Negeri 1 Samarinda tahun ajaran 2019/2020 yang dipilih dari sebelas kelas VIII. Sedangkan yang menjadi objek pada penelitian ini adalah penerapan model pembelajaran kooperatif tipe jigsaw.

Teknik pengumpulan data berupa tugas, tes, dan observasi. Tugas yang diberikan berupa Lembar Kerja Peserta Didik (LKPD). Tes berupa kuis individu, kemampuan awal, dan tes akhir siklus. Observasi berguna untuk mengetahui tingkat aktivitas guru dan siswa pada saat pembelajaran berlangsung.

Teknik analisis data yang digunakan yaitu analisis data kuantitatif. Analisis data kuantitatif berguna untuk menganalisis data tugas dalam setiap penilaian yaitu tes akhir siklus menggunakan rata-rata dan persentase.

Penelitian ini dikatakan berhasil jika ada peningkatan hasil belajar siswa dengan taraf minimal yang ditentukan $75 \%$ dari jumlah siswa yang mengikuti proses pembelajaran telah mencapai KKM sebesar 80 secara klasikal dan apabila aktivitas guru dan aktivitas siswa dalam pembelajaran minimal berkategori baik yang diukur berdasarkan lembar observasi.

\section{HASIL PENELITIAN DAN PEMBA- HASAN}

Hasil penelitian terdiri dari hasil observasi aktivitas guru dan siswa serta hasil analisis data yang diperoleh pada saat penelitian berlangsung, yaitu siklus I, siklus II, dan siklus III. Sehingga hasil analisis dari keseluruhan siklus, baik dari hasil observasi maupun hasil belajar matematika dapat dilihat pada Tabel 1 dan Tabel 2.

Tabel 1. Hasil Observasi

\begin{tabular}{|c|c|c|}
\hline \multirow{2}{*}{$\begin{array}{c}\text { Pelaksanaan } \\
\text { Pembelajaran }\end{array}$} & \multicolumn{2}{|c|}{ Hasil Observasi } \\
\cline { 2 - 3 } & $\begin{array}{c}\text { Aktivitas } \\
\text { Guru }\end{array}$ & Aktivitas Siswa \\
\hline Siklus I & Cukup & Kurang \\
\hline Siklus II & Baik & Baik \\
\hline Siklus III & Baik & Baik \\
\hline
\end{tabular}

Tabel 2. Hasil Belajar Matematika

\begin{tabular}{|c|c|c|c|c|c|}
\hline \multirow[b]{2}{*}{ Siklus } & \multicolumn{4}{|c|}{ Skor Rata-rata } & \multirow[b]{2}{*}{$\begin{array}{l}\text { Persentase } \\
\text { Peningkatan }\end{array}$} \\
\hline & LKPD & Kuis & $\begin{array}{l}\text { Tes } \\
\text { Akhir }\end{array}$ & $\begin{array}{c}\text { Hasil } \\
\text { Belajar }\end{array}$ & \\
\hline Dasar & - & - & - & 68,41 & \\
\hline $\begin{array}{c}\text { Siklus } \\
\text { I }\end{array}$ & 71,00 & 65,11 & 77,75 & 74,52 & $8,93 \%$ \\
\hline $\begin{array}{c}\text { Siklus } \\
\text { II }\end{array}$ & 81,88 & 85,72 & 79,16 & 80,70 & $8,29 \%$ \\
\hline $\begin{array}{c}\text { Siklus } \\
\text { III }\end{array}$ & 90,88 & 86,23 & 78,63 & 81,93 & $1,52 \%$ \\
\hline
\end{tabular}

Permasalahan awal sebelum melaksanakan pembelajaran kooperatif tipe jigsaw adalah nilai matematika siswa yang masih dibawah KKM pada materi teorema pythagoras walaupun materi tersebut telah dipelajari sebelumnya, hal ini dapat dilihat pada nilai rata-rata tes kemampuan awal siswa yaitu 68,41. Pada siklus I ini peneliti 
merencanakan materi yang disampaikan selama penelitian berlangsung dan disesuaikan dengan silabus sekolah. Guru membagi siswa dalam beberapa kelompok berdasarkan nilai tes kemampuan awal untuk mengerjakan tugas LKPD. Materi yang disampaikan yaitu mengenal lingkaran serta hubungan antara sudut pusat dan sudut keliling.

Berdasarkan hasil observasi pada siklus I aktivitas guru dikategorikan cukup dan aktivitas siswa dikategorikan kurang karena siswa belum bisa menyesuaikan proses belajar dengan model pembelajaran kooperatif tipe jigsaw, banyak siswa yang tidak aktif berdiskusi, dan beberapa siswa asyik mengobrol dengan temannya. Selama proses belajar peneliti harus lebih memberikan perhatian secara merata terhadap siswa dan memotivasi siswa agar lebih aktif dalam proses pembelajaran.

Pada siklus I nilai rata-rata hasil belajar matematika siswa dengan nilai dasar 68,41 meningkat menjadi 74,52 atau meningkat sebesar $8,93 \%$, persentase ketuntasan siswa meningkat sebesar 37,50\% atau sebanyak 12 siswa yang memenuhi kriteria nilai KKM, dan poin peningkatan meningkat sebesar 21,88 dengan kriteria baik.

Berdasarkan hasil observasi pada siklus II yang menjadi materi yaitu menentukan panjang busur, luas juring, dan luas tembereng serta melukis garis singgung persekutuan luar dua lingkaran. Pada siklus II, siswa mulai terbiasa dengan proses pembelajaran kooperatif tipe jigsaw, beberapa siswa sudah mulai aktif berdiskusi, guru sudah mulai memberi perhatian kepada seluruh siswa sehingga terlihat kemajuan pada aktivitas guru dan siswa dalam lembar observasi yaitu berkategori baik, namun ada satu yang menjadi indikator peningkatan yang belum tercapai adalah ketuntasan belajar klasikal.

Pada siklus II nilai rata-rata hasil belajar matematika siswa dengan nilai siklus I 74,52 meningkat menjadi 80,70 atau meningkat sebesar $8,29 \%$, persentase ketuntasan siswa meningkat menjadi $71,88 \%$ atau sebanyak 23 siswa yang memenuhi kriteria KKM, dan poin peningkatan meningkat menjadi 23,59 dengan kriteria baik.

Berdasarkan hasil observasi pada siklus III aktivitas guru dikategorikan baik dan aktivitas siswa dikategorikan baik. Pada siklus III, siswa sudah terbiasa dengan model pembelajaran kooperatif tipe jigsaw, pembelajaran telah berjalan secara kondusif karena tidak ada yang mengobrol saat diskusi berlangsung dan siswa lebih aktif dalam berdiskusi serta lebih mudah diatur. Kemajuan ini berdampak pada nilai hasil belajar siswa.

Pada siklus III nilai rata-rata hasil belajar matematika siswa dengan nilai siklus II 80,70 meningkat menjadi 81,93 atau meningkat sebesar $1,52 \%$, persentase ketuntasan siswa meningkat menjadi $78,13 \%$ atau sebanyak 25 siswa yang memenuhi kriteria KKM, dan poin peningkatan meningkat sebesar 22,50 dengan kriteria baik.

Setelah melakukan tindakan sebanyak tiga siklus maka dapat diketahui setiap siklusnya terdapat peningkatan hasil belajar dan pada siklus ketiga semua indikator keberhasilan tercapai, yaitu nilai rata-rata hasil belajar siswa mencapai KKM, hasil observasi guru dan siswa dikategorikan baik, dan siswa yang lulus lebih dari $75 \%$.

\section{KESIMPULAN}


Berdasarkan hasil penelitian yang telah dilaksanakan dapat disimpulkan bahwa model pembelajaran kooperatif tipe jigsaw dapat meningkatkan hasil belajar matematika siswa pada materi lingkaran di kelas VIII.

\section{DAFTAR PUSTAKA}

Asmani, J. M. (2011). Tips Pintar PTK: Penelitian Tindakan Kelas. Laksana.

Jihad, A. (2008). Pengembangan Kurikulum Matematika (Tinjauan Teoritis dan Historis). Multi Perssindo.

Jihad, A. dan A. H. (2009). Evaluasi Pembelajaran. Multi Perssindo.

Kurniasih, I. dan B. S. (2017). Ragam Pengembangan Model Pembelajaran untuk Peningkatan Profesionalitas Guru. Kata Pena.

Purwanto. (2016). Evaluasi Hasil Belajar. Pustaka Pelajar. 